\title{
Intellectual Capital: A Comparative View between Enterprises and Universities
}

\author{
Vanessa Pertuz Peralta ${ }^{\#}$, Maribel Bermúdez Rojo ${ }^{*}$, Neida Boscán Romero^, Carlos Solórzano Bastidas\#, \\ Adith Pérez Orozco ${ }^{+}$ \\ ${ }^{\#}$ Universidad de Santander UDES, Facultad de Ingenierías, Grupo de Investigación Nuevas Tecnologías-UDES \\ Valledupar, Colombia, Carrera $6 N^{\circ} 14-27$ Valledupar, Cesar, Colombia, 20005 \\ E-mail:van.pertuz@mail.udes.edu.co,vanesapertuz@hotmail.com, adi.perez@mail.udes.edu.co \\ *Universidad de la Guajira. Colombia, integrante grupo de investigación PROINVES, Riohacha, La Guajira, Colombia \\ E-mail: mbermudez@uniguajira.edu.co
}

^Profesora Titular de la Universidad Rafael Belloso Chacín, Coordinadora de la Línea de Gerencia de la Tecnología, Maracaibo, Venezuela E-mail: nbosca@urbe.edu.ve

${ }^{\$}$ Profesor integrador y profesor de inglés en todos los grados de educación básica del Liceo los Robles, Maracaibo. Venezuela. E-mail: carlossolorzano195@gmail.com

\begin{abstract}
This paper analyses the approaches of intellectual capital in enterprises and universities. It aims to the conceptualization, classification, and measurement of intellectual capital, and then it compares both approaches. The research is supported by the theories of Fazlagic, Alama, Molina, Sanchez, Elena and Castrillo, Paździor and Paździor and Bratianu. The study is done through bibliometrics, using a kind of descriptive, documentary research; with a non-experimental, and transversal design. The population is finite and represented by papers, conference proceedings, and thesis published between 2005-2014. To collect the primary data was used the direct observation technique, through concept analysis. We conclude, based on the results, generally, enterprises use the paradigm of fixed capital, focus on relational capital, while in universities the paradigms changed to the dynamic, Newtonian, integrating and transformational intellectual capital, based on human capital. Additionally, that as much as in the universities as in the enterprises the intellectual capital improved the performance of the organization, thus, the revision of the literature states that the results generated by the effective management of the intellectual capital are sustained in the time because of its immaterial nature. Moreover, in the enterprises, the predominant components correspond to the relational capital such as clients, suppliers, strategic alliances and the company reputation in front of the clients, which are essential for the generation of knowledge and the development of innovation.
\end{abstract}

Keywords - intellectual capital; comparative view; universities; enterprises

\section{INTRODUCTION}

A look through the intellectual capital in the literature shows many of the studies on the subject are based on the hypothesis that intellectual capital significantly influences the enterprises, institutions, and organizations creation value. Nowadays, enterprises use diverse resources available in order to grow in the market and enhance its value, purpose in which knowledge is established as the most important organizational asset. Consequently, intellectual capital is a central element in the management of organizations. In this regard, Reed, Lubatkin, and Srinivasan [1] cited by Alama [2] put emphasis on the role of intangible resources and capabilities of the company (intellectual capital) in gaining a greater competitive advantage. Similarly, Teece [3] establishes the importance of intellectual capital as a key element to facilitate business competitiveness. In the same way, Obeso [4] argues that knowledge is becoming a critical factor of production; for this reason, the enterprises must make conscious investment data collection, development of knowledge, seeking collaboration and knowledge sharing, in order to exploit in depth, the benefits of intellectual capital.

Despite recognition of the importance of intellectual capital to create value in organizations, its measurement presents difficulties because of its intangible nature. In this regard, there are different proposals in the literature for measurement, "the research in this field is still in its experimental stage" [2]. Thus, the development and 
measurement of intellectual capital have been a phenomenon of countries with high economic development, however, in most developing or emerging countries, Latin America, the valuation of intellectual capital has not been priority issue within their organizations [5].

Molina [5] argues, faced with the conceptualization of intellectual capital, that "there is no single accepted definition of what is meant by Intellectual Capital, being a recent concept is still no generalization." Despite this, then present some concepts of intellectual capital, referred to by Molina [5].

Sveiby [6] proposes that intellectual capital helps explain the difference between the market value and the book value of the enterprises because intellectual capital is not included in the financial accounts. The total market value of the enterprises is formed by the tangible, visible equity plus three types of intangible assets: the organization, customers, and the people so that the market value of the company can be interpreted as a direct reflection in the invisible balance sheet. In the same way, Brooking [7] expresses the term intellectual capital refers to the combination of intangible assets that allow the company to operate.

Meanwhile, Bontis [8] defines intellectual capital as the causal link between human capital, relational and organizational capital. Lev [9] states that intellectual capital represents the main relationships, generating intangible assets, including innovation, organizational and human resources practices.

Edvinsson and Malone [10] describe intellectual capital as the possession of knowledge, applied experience, organizational technology, customer relationships and professional skills that give the company a competitive advantage in the market. In other hand, Bueno [11] explicates it as the accumulation of knowledge that creates value or cognitive wealth owned by an organization, composed of a set of intangible assets (intellectual) or knowledge-based resources and capabilities, which when put action, as determined strategy, combined with the physical or tangible capital, is able to produce goods and services and create competitive advantages or core competencies in the market for the organization.

Botero [12] defines "an identifiable non-monetary asset without physical substance nature; the organization requires a fundamental raw material for the production or supply of goods or services; It materializes in the knowledge that all its members possess" p.68. In synthesis, the result of analysis of the definitions of intellectual capital contained in this section is evidence that all authors agree that intellectual capital is a non-cash intangible asset or physical nature, which creates value and competitive advantage to a company, organization or institution.

This paper aims to analyze the approach of intellectual capital in enterprises and universities, by reviewing the literature on the conceptualization of intellectual capital, its classification and the models used for measurement. To that end, the paper is structured as follows: in a first step, the theoretical framework is presented according to the authors considered in the literature review. After, the associated methodological issues arise with the development of research. Then, results are described through analysis matrix vision of the concept of intellectual capital in enterprises and universities, and finally, the conclusions of the investigation are presented.

\section{MATERIAL AND METHOD}

The present study aimed at analyzing the approaches made by enterprises and universities intellectual capital can be considered a type of descriptive research [13]; documentary [14], characterized by design not experimental, cross-sectional research [15] and bibliometric [16].

The population of this work is finite and objective type [15]. In the first step, we conducted an extensive search in different open access databases, such as emeraldinsight; conferences proceedings on the subject, such as International Conference on Intellectual Capital, Knowledge Management, and Organizational Learning; and $\mathrm{Ph} . \mathrm{D}$. thesis repositories in Colombia, Mexico, Venezuela and Spain. The authors carried out the search looking for the keywords: intellectual capital in universities, intellectual capital in companies, management of intellectual capital in companies and universities; and new alternatives for the administration of intellectual capital. In a second step, the documents with the highest number of citations are selected. we picked the most relevant document in each year, during the period of time observed. The researchers are aware of the impossibility of covering all the material published in one specific topic. For this reason, we chose the 6 papers that meet the inclusion criteria and intersect in the management of intellectual capital in the two study.

The Primary data were obtained through the direct observation technique, using an analysis matrix [14], in which the author, title of the research conducted, vision concept specified capital intellectual capital, an area in which the main findings of the referenced authors are presented and the approach to which they are addressed, in this case, enterprises or universities also, we used to meet the overall objective of this research sheet [12].

\section{RESULTS AND DISCUSSION}

In order to analyze the present approaches to intellectual capital in enterprises and universities were analyzed six (6) journal papers, within them, there are highlight the theories regard the variable involved.

The documents analyzed are focused on the intellectual capital variable, published in the period between 2005-2014. This time interval was sufficient to achieve the objective of this research and observes the theories under the previously selected parameters search by keywords intellectual capital, comparative view, universities, enterprises. The relevant aspects resulted in the investigation are shown in Table 1.

Next, the paper expands the postulates of each of the authors presented in Table 1:

Fazlagic [17] in the paper "Measuring the intellectual capital of a University" analyzes some fundamental challenges regarding the measurement of the intellectual capital in European universities, especially those located in central and eastern Europe, characterized by a low innovation rate, weak links with the industry and poor human resources management policies.

In addition, the author states that "the intellectual capital of a university consists of human capital and structural 
capital." Specifically, human capital refers to the individual skills of researchers. In the global economy and the growing demand for qualified research staff, the human capital of the universities is very unstable, so those universities that do not invest in human capital have a high risk of losing it [17].

Consequently, Fazlagic [17] proposed a matrix for measuring intellectual capital in universities, where indicators for measuring resources, activities, and results of human capital and structural capital are described. With regard to resources for human capital measurement, the proposed indicators are associated with the number of researchers; investigators share of total employment and the average age of them. Meanwhile, indicators correspond to activities research investment per employee and the time spent in seminars; in contrast, the indicators for measuring the results of human capital include, among others, the number of publications per researcher, satisfaction and staff turnover.

Similarly, the indicators for measuring structural capital resources proposed by Fazlagic [17] are the number of computers per employee, total departments, each department spending and participation of women in management positions. For measuring structural capital activities, are established as indicators of total investment in infrastructure for research, the number of research projects in process and the number of researchers attending conferences. Also, for measuring the results of structural capital related to the number of international researchers' indicators are established, the recognition of the university, the number and satisfaction of students and the number of courses offered.
Fazlagic [17] suggests that measuring intellectual capital is emerging as an important determinant to increase the productivity of knowledge work, so that "the measurement system of intellectual capital to help organizations involved to identify what it works - and what does not work ".

The paper concludes that intellectual capital (IC) reporting models applied in the eastern Europe Universities are still in at an embryonic stage because the IC measurement should be thought of as a platform for discussion about intangible assets. The content of IC report should, therefore, provoke questions - not just give all the answers. The authors of IC reports shun from leaving the room for ambiguity--inspired by the accuracy of financial statements they try to copy the structure of a balance sheet. Instead, IC reports should include a certain number of questions and scenarios, which the management will try to analyze. Making the acquisition and application of IC 'discussable' improve prospects for informed decision making that can mobilize changes in the business agenda. Additionally, the measurement of IC in the Universities is essential if the higher education system is to continuously regenerate itself by the intelligent use of knowledge management.

The introduction of such methods requires building awareness among the senior academics occupying management positions at universities, creating an IC measurement task force, the introduction of IC measurement methodologies and timely and complex implementation and publication of the results.

TABLE I

SPECIALIZED JOURNAL PAPERS S ON INTELLECTUAL CAPITAL YEARS (2005-2014)

\begin{tabular}{|c|l|c|}
\hline Author & \multicolumn{1}{|c|}{ View of the concept of intellectual capital } & Approach \\
\hline$[17]$ & $\begin{array}{l}\text { The measurement of IC in the Universities is essential if the higher education system is to continuously } \\
\text { regenerate itself by the intelligent use of knowledge management. However, intellectual capital (IC) reporting } \\
\text { models applied in the eastern Europe Universities are still in at an embryonic stage. }\end{array}$ & Universities \\
\hline$[2]$ & $\begin{array}{l}\text { There is a consensus in the literature regarding the number of components of intellectual capital and its name: } \\
\text { human capital, structural capital and relational capital. Additionally, the interaction between the intangible } \\
\text { assets of the organization increases the performance of it. }\end{array}$ & Enterprises \\
\hline$[18]$ & $\begin{array}{l}\text { This paper suggests to move one step forward and discuss current challenges in relation to establishing } \\
\text { standards for universities to manage and report on their IC and the difficulties in capturing the process } \\
\text { dynamics. Moreover, the investigation established a report intellectual capital designed that must identify } \\
\text { intangible assets relating to the creation of value from strategic objectives. }\end{array}$ & Universities \\
\hline$[5]$ & $\begin{array}{l}\text { The methodologies to assess the intellectual capital in the organization are not easily applied because the } \\
\text { knowledge of the subject is in an embryonic phase, where there are no proven and accepted methodologies. } \\
\text { Thus, measurement models perform very static analysis that difficult to understand. }\end{array}$ & Enterprises \\
\hline$[19]$ & $\begin{array}{l}\text { The paper was focused on synthetic and analytical methods which are most often applied when measuring the } \\
\text { effectiveness of company's intellectual capital. Intellectual capital, identified with human capital, human } \\
\text { resources, intellectual property, intellectual assets, or knowledge resources, in the age of knowledge-based } \\
\text { economy plays a crucial role almost in each organization. }\end{array}$ & Enterprises \\
\hline$[20]$ & $\begin{array}{l}\text { The main limitation of the static and dynamic models developed so far come from the fact that intellectual } \\
\text { capital is considered by definition as a potential. The entropic intellectual capital is the first to introduce the } \\
\text { concept of intellectual capital transformation from its potential stage to its operational stage through the action } \\
\text { of the organizational integrators. }\end{array}$ & Universities \\
\hline
\end{tabular}

Alama [2] in her thesis "Intellectual capital and business performance in professional services firms in Spain" determined that there is a consensus in the literature regarding the number of components of intellectual capital and its name: human capital, structural capital and relational capital. Relevant in each of the dimensions of intellectual capital dimensions identified. Human capital (7 dimensions): knowledge/education/professional development, skills, retention, training, experience, creativity, motivation. Structural Capital (5 dimensions): expertise in information technology, ways of holding knowledge, culture/values, structure/systems/processes, innovation/R \& D. Relational 
Capital (4 dimensions): customers, suppliers, alliances, reputation.

The analysis of business results of intellectual capital is concentrated in three areas: financial, market and innovation, concluding that human capital attributable to higher corporate earnings are sustainable over time because of the intangible nature and socially complex human capital. Additionally, it is concluded that the interaction between the intangible assets of the organization increases the performance of it. The research concludes that intangible assets specifically the experience and skills, culture, technology skills information, alliances, reputation and customer relations are of great importance in the generation of new knowledge resulting in the successful launch of services and new projects. Moreover, the main innovation ideas often come from customers when there is a good relationship with them, as well as allied enterprises. It is also to highlight the significance of alliances and reputation on firm performance.

According to the findings in Alama [2], the literature sees clearly the convergence in the number of major components of intellectual capital (Table 1). However, she suggests that there are differences in the terminology for each component. The first component is linked to the people and in most of the studies reviewed it is called human capital. The second component refers to processes, structures, technology, and innovation and called structural capital, although authors like Brooking [7], Chen, Zhu and Yuan [21] separated the technological aspect of the organization. The last component refers to the ratio of the company mainly with the client, and is called in most of the studies reviewed by Alama [2], customer equity work; however, the relationship of the company is of a broader spectrum as it relates to other related agents, such as suppliers and partners [6], because the name of relational capital is adopted used by Euroforum Escorial [22] and Ordoñez [23].

Alama [2] states that "the aforementioned components represent intangible assets of a different nature, each of which works in a certain way in achieving business goals, interacting with each other" p.69. Thus, individuals knowledge, skills, and cooperation's spirit, represent human capital, and are valuable assets to the company, however, it requires an organizational platform for the suitable development of their work, such as information systems, procedures, and infrastructure that configures the structural capital, also, there should be appropriate channels to establish strong links with the agents which the company relates: customers, suppliers, and others, which is the relational capital of the organization. Table 2 presents the names of each of the components of intellectual capital, according to different authors.

TABLE II

TyPOLOGY OF INTELLECTUAL CAPITAL [2]

\begin{tabular}{|c|c|c|c|c|c|}
\hline Models and Authors & Human capital & \multicolumn{2}{|l|}{ Structural Capital } & \multicolumn{2}{|c|}{ Relational Capital } \\
\hline Balanced Scorecard [24] & $\begin{array}{l}\text { Learning and Growth } \\
\text { perspective }\end{array}$ & \multicolumn{2}{|c|}{ Internal Processes Perspective } & \multicolumn{2}{|c|}{ Customer Perspective } \\
\hline [25] & Human capital & \multicolumn{2}{|c|}{ Structural Capital } & \multicolumn{2}{|c|}{ Capital Client } \\
\hline Technology Broker [7] & $\begin{array}{l}\text { Centered on the individual } \\
\text { assets }\end{array}$ & $\begin{array}{c}\text { Intellectual } \\
\text { Property Assets }\end{array}$ & $\begin{array}{l}\text { Infrastructure } \\
\text { Assets }\end{array}$ & \multicolumn{2}{|c|}{ Market Assets } \\
\hline $\begin{array}{l}\text { Intangible Assets } \\
\text { Monitor [6] }\end{array}$ & Competence & \multicolumn{2}{|c|}{ Internal Structure } & \multicolumn{2}{|c|}{ External Structure } \\
\hline Skandia Navigator dec [10] & Human Approach & \multicolumn{2}{|c|}{ Process Approach } & \multicolumn{2}{|c|}{ Client Approach } \\
\hline$[10]$ & Human capital & \multicolumn{2}{|c|}{$\begin{array}{l}\text { Structural Capital: Organizational } \\
\text { Capital and Customer Capital }\end{array}$} & & \\
\hline [8] & Human capital & \multicolumn{2}{|c|}{ Structural Capital } & \multicolumn{2}{|c|}{ Capital Client } \\
\hline Intellect [22] & Human capital & \multicolumn{2}{|c|}{ Structural Capital } & \multicolumn{2}{|c|}{ Relational Capital } \\
\hline$[26]$ & Human capital & \multicolumn{2}{|c|}{$\begin{array}{l}\text { Structural Capital: Innovation Capital } \\
\text { and Processes Capital }\end{array}$} & \multicolumn{2}{|c|}{$\begin{array}{l}\text { Social Capital: intrasocial capital, } \\
\text { Intersocial capital and Innovation } \\
\text { capital }\end{array}$} \\
\hline Intellectus [27] & Human capital & $\begin{array}{l}\text { Technology } \\
\text { Capital }\end{array}$ & $\begin{array}{l}\text { Organizational } \\
\text { Capital }\end{array}$ & Business Capital & Capital stock \\
\hline$[28]$ & Human capital & \multicolumn{2}{|c|}{ Internal Capital } & \multicolumn{2}{|c|}{ External Capital } \\
\hline [11] & Human capital & $\begin{array}{l}\text { Technology } \\
\text { Capital }\end{array}$ & $\begin{array}{l}\text { Organizational } \\
\text { Capital }\end{array}$ & Business Capital & Stock Capital \\
\hline [21] & Human capital & Capital Innovation & Structural Capital & \multicolumn{2}{|c|}{ Client Capital } \\
\hline [29] & Human capital & \multicolumn{2}{|c|}{$\begin{array}{l}\text { Structural Capital: Internal capital, } \\
\text { External capital and Innovation capital }\end{array}$} & & \\
\hline [23] & Human capital & \multicolumn{2}{|c|}{$\begin{array}{l}\text { Structural Capital: Technology capital } \\
\text { and Organizational capital }\end{array}$} & \multicolumn{2}{|c|}{ Relational Capital } \\
\hline
\end{tabular}

Sanchez, Elena y Castrillo [18] in the paper "Intellectual capital dynamics In universities: a reporting model" suggests a model for reporting and managing intellectual capital (IC) in universities and research organization, which contains financial indicators for resources related to research activity; and non-financial indicators associated with people involved in these activities, on the other hand, to move one step forward and discuss current challenges in relation to establishing standards for universities to manage and report on their IC and the difficulties in capturing the process dynamics 
Moreover, the investigation established a report intellectual capital designed around the specific characteristics of the organization; this report must identify intangible assets relating to the creation of value from strategic objectives. Additionally, the report's proposal is an attempt to standardize the indicators in each university. This, accompanied by a cultural change in the academic community, oriented to accept the changes in the structures and working methods. Also, there is growing evidence in support of the application of IC tools in universities and the potential benefits this would bring. However, it should be acknowledged that steps are still to be taken, most at the supranational level, in order to reflect university dynamics and allow the IC report to serve as both a response to the institution's accountability needs and an improvement of its management practices.

Molina [5] in the thesis "Intellectual Capital valuation in a Colombian enterprise" focuses on the concept of Intellectual Capital. To do so, perform a search process information and state of the art of existing methodologies to assess the intellectual capital in the organization, From the review, it concludes that the methodologies are not easily applied because the knowledge of the subject is in an embryonic phase, where there are no proven and accepted methodologies. Thus, measurement models perform very static analysis that difficult to understand.

The author suggests that it is impossible to produce a universal model for measurement intellectual capital, but these are an essential basis for enterprises to begin to define their own model must be fully linked to its strategy. The model must be open and flexible to facilitate their adaptation to changes in the business environment and, consequently, the goal is to produce a balanced remuneration system that contains all the dimensions of human beings and that bring real value to the company.

Additionally, the paper highlights the difficulty of measuring the ability to generate the future value of intangible assets, why, set right indicators to measure them is difficult. However, it suggests that it may be more difficult to overcome institutional inertia. This, because the intellectual capital should be viewed not only there to manage it, which implies that the information should be an input to rethink the organization. Accordingly, the intellectual capital report must be an active, dynamic and easy to understand the document, which must contain not only the appropriate indicators but also present them in a format that is easily understandable, applicable and comparable between different enterprises.

Paździor y Paździor [19] in the paper "Measurement of intellectual capital in a company" aims the definitions, classifications, and methods of evaluation of intellectual capital. The attention was focused on synthetic and analytical methods which are most often applied when measuring the effectiveness of company's intellectual capital. Intellectual capital, identified with human capital, human resources, intellectual property, intellectual assets, or knowledge resources, in the age of knowledge-based economy plays a crucial role almost in each organization. Such a situation makes a credible reflection of its value and effectiveness a priority in the process of increasing the competitive advantage of a company.
According to the conducted literature review of measurement methods of intellectual capital effectiveness, it seems that the evaluation process of values of intangible resources is necessary for a company's strategy implementation. Still, there is no a synthetic indicator which would fully reflect the value of the most precious resource of a 21st-century organization, which is intellectual capital. This paper concludes that in many enterprises, intellectual capital is the most valuable resource. It is important, as a full reflection in reporting of intellectual capital value, in the opinion of many managers, will contribute to higher effectiveness in personnel strategy of enterprises.

Thanks to the growing efficacy of measurement methods of intellectual capital, it seems possible to pursue more completely the primary goal of enterprises, which is the maximization of value in a long period. Value is important first of all from the point of view of employees, whose work in many cases is not assessed in a proper way, which would enable elimination of unprofessional factors, and focus on behaviors increasing the effectiveness of the whole organization.

According Paździor and Paździor [19], "intellectual capital management and the impact assessment is not possible without measurement," p.845, however, this measurement is a difficult task, considering the intellectual capital of a company is strictly related to the type of activity, the business environment, the history and culture of a particular organization. Therefore, according to the authors, "perhaps a universal or technical model for the evaluation of the capital never has been developed". Product literature on the methods of measuring intellectual capital, the authors suggest that there are many methods of measuring intellectual capital. However one of the most widespread classifications of these methods proposes the existence of two categories: synthetic methods and analytical methods.

1) Synthetic Methods: This method is based on the assumption that the market price of the shares always reflects the real value of a company. Thus the accidental factors have no impact on it. The weakness of this method is the high sensitivity of the company's values of the intellectual capital against the changes occurring in the environment, for example, market deregulation [19].

2) Analytical Methods: One of the known analytical methods is the Skandia Navigator, which carries the name of the first company that made an attempt to calculate the intellectual capital. The model in question contains 164 measurement indicators, which are divided into intellectual (91) and traditional (73). These indicators cover five business areas: financial, customer, processes, human resources and development, within each area, there is a specific set of programs to the description of intangible resources [19].

3) Measurement Methods of Intellectual Capital in Universities: As proposed by Fazlagic [17] one of the most promising frameworks to measure university intellectual capital developed in Denmark by the Danish Agency for Trade and Industry, this model presents the intellectual capital in the form of resources, activities, and results. According to the author, "thanks to this taxonomy is possible to understand the paradox: why the well-established 
European universities do not produce knowledge of the highest quality. The high potential (resources) present in universities in many cases goes hand in hand with their poor performance (results)" p.4.

Bratianu [20] in the paper "Intellectual capital of the European universities" compared the main intellectual capital models, from the pioneering ones developed by Sveiby [6] and Edvinsson and Malone [10], to the canonical model accepted almost by all researchers, and from the dynamic models developed by Nonaka and Takeuchi [30] and Nissen [31] to the entropic intellectual capital developed by Bratianu, concluding that the main limitation of the static and dynamic models developed so far come from the fact that intellectual capital is considered by definition as a potential. The entropic intellectual capital is the first to introduce the concept of intellectual capital transformation from its potential stage to its operational stage through the action of the organizational integrators. In their view, an integrator is a powerful field of forces capable of combining two or more elements into a new entity, based on interdependence and synergy. Additionally, in the model entropic evaluates the intellectual capital, as well as human capital, structural capital and relational, the cognitive capital, emotional capital, and spiritual capital is included, in order to better reflect the intellectual capital of universities. In agreement with the paper, European universities have the highest density of intellectual capital than any other organization, but its performance is not at the level of its potential; operating intellectual capital is low, and the main difficulty of this situation is the quality of its nonlinear integrators: management, leadership and organizational culture, and restrictive structural capital. In the other hand, the paper argues that the intellectual capital reports in European universities are an optional decision, with the exception of Austrian universities, that is requested to an annual report on intellectual capital as a result of the Education Act, and Intellectual Capital Act. However, the model used in this legislation is based on the canonical paradigm with its main components: human capital, structural or organizational capital and relational capital using linear indicators for evaluation. Therefore, it is essential to change the paradigm of intellectual capital, of Newtonian dynamics (static model) to thermodynamic metaphor (the entropic paradigm of intellectual capital) in order to define new indicators to reflect the intangible nature of intellectual capital [32].

Bratianu [20] suggests the existence of two intellectual capital paradigms: The static and dynamic paradigm. The static intellectual capital paradigm is based on the Newtonian static model, which is because the paradigm does not consider time as a variable, reflecting a movement of inertia [20]. Thus, the static intellectual capital paradigm conceived as an action that reflects the potential of a particular organization in a given time [33]. Therefore, to be considered as an action, intellectual capital can be acquired, accrued, combined, distributed and measured as all other tangible assets, although measurement systems may differ [34].

The paradigm of dynamic intellectual capital is based on Newtonian dynamic models that incorporate time as a fundamental variable [20]. The description of this model is based on the concept of flow of knowledge; in agreed with Nissen [31] knowledge of the organization does not exist in the form required for its application, in the place and the time required for the performance of work; because this should flow from where it is, to how and where it is needed. Thus, "Knowledge is a fluid mix of experiences, values, contextual information, and expert insight that provides a framework for evaluating and incorporating new experiences and information" [35] p.5. Consequently, changing static to the dynamic paradigm, it is that the latter displays the knowledge as a flow through the organization; knowledge is not literally located and stored within the organization [34].

The canonical model of intellectual capital represents the best known and widely used dynamic paradigm result. According to this model "intellectual capital can be defined as all monetary and physical resources that are not fully controlled by the organization and contributing to the creation of value for the organization" [36] p.19. It also states that the structure of intellectual capital is given by human capital, structural capital or organization, and the customer or relationship capital [34], [36], [37].

Human capital contains all the knowledge, skills, intelligence, intuition and values of employees. Structural capital owned contains intangible resources, and they are completely controlled by the organization: organizational structure, databases, intellectual property, processes, organizational culture, and organizational history, among other brands. And the relational capital includes the entire spectrum of relations between the organization and external business environment, especially with suppliers, customers, consumers and partners [20].

\section{CONCLUSIONS}

The main conclusions alter an analyzed bibliographic revision are shown below.

The first conclusion is that as much as in the universities as in the enterprises the intellectual capital improved the performance of the organization, thus, the revision of the literature states that the results generated by the effective management of the intellectual capital are sustained in the time because of its immaterial nature.

The revision of the papers about the intellectual capital indicates that is a general assent in the literature in front of the component of the intellectual capital: Human capital, structural capital and relational capital. However, in the university context, one of the investigations analyzed states that must be considered the cognitive capital, emotional capital a spiritual capital, in order to reflect more effective, the dynamic in front of intellectual capital in the universities.

Additionally, in the enterprises, the predominant components correspond to the relational capital such as clients, suppliers, strategical alliances and the company reputation in front of the clients, which are essential for the generation of knowledge and the development of innovation. Meanwhile, in the universities, the predominant approach is toward the human capital. Nevertheless, the concept of intangible that represent an aggregate value is immersed in both sectors. Therefore, the good intellectual capital management contributes to the positioning of both sectors.

Also, the revision of the literature considers the limitation of the model used to measure intellectual capital, because of 
its intangible nature. The authors agreed that the models provided in the literature; as in the enterprises as in the universities, compose a basis for measuring intellectual capital. However, they are in an embryonic stage and still have not been either verified or accepted, for these reasons are difficult to apply, as well, each organization should develop indicators aligned with their strategies and their own characteristics. Thus, the review of the latest literature states that besides of the associated indicators with the quantifications of the monetary value of intellectual capital. Its measurements must appraise the benefits associated with the satisfaction of the stakeholders and eco-conservation.

In the other hand, inside the limitations, we found that the existing models and perform static analysis should be relaxed to suit the enterprises' needs. This result was static prevailing paradigm for the analysis of the concept of intellectual capital; so it is necessary to change the paradigm of Newtonian dynamics to thermodynamic metaphor (dynamic paradigm) according to which knowledge is seen as a flow through the organization, which becomes its potential phase to the operational phase through the management, leadership and organizational culture that act as integrators of the organization.

Furthermore, the importance of intellectual capital's valuation in the strategy of the organization, and therefore reports the same measurement as a tool for management analysis is emphasized. However, these reports should be readily understandable and even compare different sectors, and further, should become an input to assess and improve organizational processes. There is a need for further research aimed at measurement methodologies and indicators that reflect the dynamics of intellectual capital in universities and inside the business sector. In the same way, both enterprises and universities authors draw attention to the limitation to implement new methods of intellectual capital and the change resistance on the part of employees.

This work is useful for other researchers working with an intellectual capital variable, because evidence of progress and the challenges facing this research, establishing parameters to improve the management of intellectual capital as a tool for added value in organizations, its impact strategy, and positioning

\section{REFERENCES}

[1] K. Reed, M. Lubatkin, N. Srinivasan. Proposing and Testing an Intellectual Capital-Based View of the Firm. Journal of Management Studies, v.43, p.867- 893. 2006. Available in: 〈http://papers.ssrn.com/sol3/papers.cfm?abstract_id=904895> Accessed in: 2 February 2015.

[2] E. M. Alama Salazar, Capital intelectual y resultados empresariales en las empresas de servicios profesionales de España. Departamento de Organización de Empresas; Universidad Complutense de Madrid. 2008. Available in: <http://eprints.ucm.es/8709/> Accessed in:1 March 2015.

[3] D. Teece. Strategies for Managing Knowledge Assets: the Role of Firm Structure and Industrial Context. Long Range Planning, p.3554, $2000 \quad$ Available in: <http://www.sciencedirect.com/science/article/pii/S00246301990011 7X> Accessed in: 12 February 2015.

[4] C. Obeso, Homo Faber, Homo Sapiens: Estado de la Cuestión. Ediciones del Bronce, p.23-64, 1999. Available in: <http://www.scielo.org.co/scielo.php?script=sci_nlinks\&ref=000116 \&pid=S0123-417X201400010000100016\&lng=en> Accessed in: 1 February 2015.
[5] P. A. Molina Parra, Valoración de capital intelectual en una empresa colombiana. Facultad de Minas. Universidad Nacional de Colombia, $2009 . \quad$ Available <http://www.bdigital.unal.edu.co/2416/1/43104764.2009.pdf> Accessed in: 20 February 2015.

[6] K. Sveiby. The new organizational wealth: managing and measuring knowledgebased based assets. Berrett- Koehler: New York, 1997.

[7] A. Brooking, El Capital Intelectual: El Principal Activo de las Empresas del Tercer Milenio. Barcelona: Paidos, 1997.

[8] N. Bontis, Intellectual capital: An exploratory study that develops measures and models. Management Decision, p.63-76, 1998.

[9] B. Lev, "Intangibles". Management, measurement and reporting. Brookings Institution: Washington. 2001.

[10] L. Edvinsson, M. Malone, El Capital Intelectual. Cómo identificar y calcular el valor de los recursos intangibles de su empresa. Gestión: Barcelona, 2000.

[11] E. Bueno, Génesis, evolución y concepto del capital intelectual: enfoques y modelos principales. Capital Intellectual, n.1, p.8-19, 2005.

[12] M. Tamayo. El proceso de la investigación científica. Limusa S.A: México, 5 ediciones, 2011.

[13] N. E. Botero, Gestión del Conocimiento para la administración del recurso humano "Estado del Arte". Revista Anagramas. Universidad de Medellín, 2007. Available in: <http://revistas.udem.edu.co/index.php/anagramas/article/view/744> Accessed in: 20 June 2013.

[14] Finol; Nava. Procesos y productos en la investigación documental. Editorial de la Universidad del Zulia: Venezuela, Segunda Edición, 1999.

[15] R. Hernández, C. Fernández, P. Baptista. Metodología de la investigación, Mc Graw Hill: México. D.F: Quinta Edición, 2010.

[16] M. Alcain, Bibliometría y Ciencias Sociales. 2002. Available in: <http://www.clio.redinis.es/clionet/articulos/bibliometria.htm> Accessed in: 21 August 2014.

[17] A. Fazlagic, Measuring the intellectual capital of a university. The Poznan University of Economics. In: Conference on Trends in the management of human resources in higher education. 2005. Organización para la Cooperación y el Desarrollo Económicos (OECD): Poland. Available in: <http://www.oecd.org/edu/imhe/35322785.pdf>. Accessed in: 10 April 2015.

[18] M. P. Sanchez, S. Elena, R. Castrillo. Intellectual capital dynamics in universities: a reporting model. Journal of Intellectual Capital, v.10, n.2, p.307-324. 2009. Available in: <http://www.emeraldinsight.com/doi/abs/10.1108/146919309109526 87>. Accessed in: 20 February 2015.

[19] A. Paździor, M. Paździor. Measurement of intellectual capital in a company. International Conference management, knowledge and Learning. 2012. Available in: <http://econpapers.repec.org/bookchap/isvmklp12/843-849.htm> Accessed in: 4 february 2015.

[20] C. Bratianu, Intellectual Capital of the European Universities. A.M. Dima. Hershey, p.24-43, 2014. Available in: <http://www.researchgate.net/profile/Constantin_Bratianu/publicatio n/265466316_Intellectual_Capital_of_the_European_Universities_*/ links/540f29ba0cf2f2b29a3dd5be.pdf>. Accessed in: 20 March 2015.

[21] J. Chen, Z. Zhu, H. Yuan, Measuring Intellectual Capital: a New Model and Empirical Study. Journal of Intellectual Capital, p.195212, 2004. Available in: <http://www.emeraldinsight.com/doi/abs/10.1108/146919304105130 03> Accessed in: 3 July 2012.

[22] Euroforum Escorial. Medición del Capital Intelectual. Modelo Intelect. I.U. Euroforum Escorial: Madrid, 1998.

[23] D. P. Ordoñez, Measuring and Reporting Structural Capital: Lessons from European Learning Firms. Journal of Intellectual Capital, v.5, p.629-647. 2004. Available in: <http://www.emeraldinsight.com/doi/abs/10.1108/146919304105670 59> Accessed in: 5 September 2013.

[24] R. Kaplan, D. Norton. Evaluación de los Resultados: Algo más que Números", Harvard Deusto Business Review, vol. 55, pp. 18-25, 1993.

[25] H. Saint-Onge. Tacit Knowledge. The Key to the Strategic Alignement of Intellectual Capital", Strategy \& Leadership, vol. 24, pp.10-14, 1996.

[26] M. McElroy. Social Innovation Capital, Journal of Intellectual Capital, vol. 3, pp. 30-39, 2002. 
[27] CIC. Modelo de Medición y Gestión del Capital Intelectual: Modelo Intellectus, documento de trabajo CIC, Madrid. 2003.

[28] J. Guthrie, R. Petty, K. Yongvanich. Using content analysis as a research method to inquire into intellectual capital reporting", Journal of Intellectual Capital, vol. 5, pp. 282-293. 2004.

[29] A. Joia. Are Frecuent Customer Always a Company's Intangible Asset? Some Findings drawn from an Exploratory Case Study", Journal of Intellectual Capital, vol. 5, pp. 586-601, 2004.

[30] I. Nonaka, H. Takeuchi. La organización creadora de conocimiento. Como las compañías japonesas crean la dinámica de la innovación. México: Oxford University Press, 254, 1999.

[31] M. Nissen, Harnessing knowledge dynamics. Principled organizational knowing and learning. IRM Press: London, 2006.

[32] D. Andriessen, Stuff or love? How metaphors direct our efforts to manage knowledge in organizations. Knowledge Management Research \& Practice, 2008. Available in: <http://www.palgravejournals.com/kmrp/journal/v6/n1/full/8500169a.html > Accessed in: 1 January 2014.
[33] J. A, Chatzkel, Conversation with Hubert Saint-Onge. Journal of Intellectual capital. 2002. Available in: <http://www.hrd.nida.ac.th/fileupload/paper/teacher/5.3.\%20A\%20C onversation $\% 20$ with $\% 20$ Hubert $\% 20$ Saint $\% 20$ Onge.pdf $>$ Accessed in: 2 June 2013.

[34] D. Andriessen. Making sense of the intellectual capital. designing a method for valuation of intangibles. Elsevier ButterworthHeinemann, 2004.

[35] T. Davenport, L. Prusak, Working knowledge. How organizations manage what they know. Harvard Business School Press, Boston. 2000 Available

in: <http://wang.ist.psu.edu/course/05/IST597/papers/Davenport_know. pdf $>$ Accessed in: 2 November 2012.

[36] G. Roos, S. Pike, L. Fernström, Managing intellectual capital in practice. Elsevier: Amsterdam, 2005.

[37] T. Stewart. Intellectual capital: the new wealth of organizations, 1999. 